\title{
ANALISIS KURIKULUM PENDIDIKAN AGAMA ISLAM DI INDONESIA DAN THAILAND \\ Studi Kebijakan Kurikulum 2013 dan Kurikulum 2008 di Tingkat SMA
}

\author{
Fauzan \\ Fakultas Ilmu Tarbiyah dan Keguruan UIN Syarif Hidayatullah, Jakarta, \\ Indonesia \\ fauzan@uinjkt.ac.id \\ Ayup Lateh \\ Fakultas Ilmu Tarbiyah dan Keguruan UIN Syarif Hidayatullah, Jakarta, \\ Indonesia \\ ayublateh@hotmail.com \\ Fatkhul Arifin \\ Fakultas Ilmu Tarbiyah dan Keguruan UIN Syarif Hidayatullah, Jakarta, \\ Indonesia \\ fatkhul_arf@uinjkt.ac.id
}

\begin{abstract}
THE CURRICULUM ANALYSIS OF ISLAMIC EDUCATION IN INDONESIA AND THAILAND (THE STUDY OF CURRICULUM 2013 AND CURRICULUM 2008 IN SENIOR HIGH SCHOOL LEVEL). This study aims to determine the concept of Islamic education in Curriculum 2013 in Indonesia and Curriculum 2008 in Thailand at the high school level (SMA). This research is qualitative research by the use of a literature study approach. The results of the study that: a) The policy of Curriculum 2013 in Indonesia and Curriculum 2008 in Thailand refers to the law of the national education system in each country. b) Both curricula share the graduate competency standards (SKL) in common, being pious and skillful person in life, c) The content standard of both curricula refers to (SKL) in Indonesia, it is derived to be the core competence standard
\end{abstract}


(KI) and basic competence (KD) while Curriculum 2008, it is derived to be learning standard (SP) and basic competence (KD), d) The Process Standard in Curriculum 2013 is implemented through a scientific approach which consists of observing, questioning, associating, experimenting, and networking. Meanwhile, Curriculum 2008 is implemented in a studentcentered approach with consists of an integrated approach, thinking, creating knowledge and social, problem-solving, learning from experience, direct practice, research, independent learning, and moral action. e) Assessment standard In Curriculum 2013, used as an authentic assessment which consists of an assessment test (paper and pencil test), performance, project, and portfolio for all grades in all educational system levels. However, Curriculum 2008 assessed by using personal communication assessment, performance assessment, authentic assessment, and portfolio for all grades in every national education system level.

Keywords: Islamic education subject; Curriculum 2008; Curriculum 2013.

\begin{abstract}
Abstrak
Penelitian ini bertujuan untuk mengetahui konsep pendidikan Islam dalam Kurikulum 2013 di Indonesia dan Kurikulum 2008 di Thailand di tingkat sekolah menengah. Penelitian ini adalah penelitian kualitatif dengan menggunakan pendekatan studi literatur. Hasil penelitian menunjukkan bahwa: a) Kebijakan Kurikulum 2013 di Indonesia dan Kurikulum 2008 di Thailand mengacu pada hukum sistem pendidikan nasional di setiap negara. b) Keduanya memiliki standar kompetensi lulusan yang sama, yaitu menjadi orang yang saleh dan terampil dalam kehidupan, c) Standar konten kedua kurikulum mengacu pada SKL, di Indonesia diturunkan menjadi standar kompetensi inti dan kompetensi dasar sedangkan Kurikulum 2008, diturunkan menjadi standar pembelajaran dan kompetensi dasar, d) Standar Proses dalam Kurikulum 2013 diimplementasikan melalui pendekatan ilmiah yang terdiri dari mengamati, mempertanyakan, mengaitkan, bereksperimen, dan berjejaring. Kurikulum 2008 diterapkan dalam pendekatan yang berpusat pada siswa dengan terdiri dari pendekatan terpadu, berpikir, menciptakan pengetahuan dan sosial, pemecahan masalah, belajar dari pengalaman, praktik langsung, penelitian, pembelajaran mandiri, dan tindakan moral. e) Standar penilaian Kurikulum 2013 menggunakan penilaian otentik yang mencakup tes, kinerja, proyek, dan portofolio untuk semua nilai di semua tingkatan. Kurikulum 2008 dinilai dengan menggunakan penilaian komunikasi pribadi, penilaian kinerja,
\end{abstract}


penilaian otentik, dan portofolio untuk semua nilai di setiap tingkat sistem pendidikan nasional.

Kata kunci: Mata pelajaran pendidikan agama Islam, Kurikulum 2008, Kurikulum 2013

\section{A. Pendahuluan}

Pendidikan sebagai upaya mengembangkan dan meningkatkan kualitas peserta didik dilakukan dalam upaya mencapai tujuan pendidikan. Pendidikan adalah suatu proses pembelajaran yang terus menerus diusahakan dan diatur sedemikian rupa agar mendapatkan hasil yang memuaskan. Namun, setiap kegiatan yang diadakan tidak lepas dari tantangan dan rintangan. Di antara tantangan pendidikan yang sering terdengar adalah kurikulum Pendidikan Agama Islam (PAI) pada satuan pendidikan. Secara induktif, sumber-sumber kurikulum PAI sekarang ini berasal dari berbagai aspek yang berlainan, padahal asas utama bagi kurikulum Pendidikan Agama Islam pada dasarnya berpijak al-Quran dan al-Hadis yang merupakan rujukan utama dalam pendidikan Islam.

Selain komponen pendidik dan peserta didik, kurikulum merupakan komponen terpenting dalam proses pendidikan, keberadaanya saling terkait satu sama lain. Kurikulum tidak hanya dipahami sebagai suatu materi atau rencana yang dipakai oleh pengajar sebagai acuan dalam menjalankan profesinya dalam pembelajaran di kelas. Lebih dari itu, keberadaan kurikulum juga menjadi keharusan bagi suatu lembaga pendidikan dalam rangka mewujudkan cita-cita dan tujuan pendidikan nasional, yang sudah diatur dalam undangundang, dimana outputnya diharapkan mampu menjawab berbagai kebutuhan masyarakat saat ini.

Perubahan kurikulum di Indonesia telah mengalami beberapa kali perubahan, perubahan terakhir yakni dari KTSP ke kurikulum 2013. Perubahan Kurikulum KTSP 2006 ke Kurikulum 2013 adalah salah satu upaya pemerintah untuk menyempurnakan kurikulum, hal tersebut tentunya dilakukan setelah melakukan berbagai evaluasi yang disesuaikan dengan kebutuhan anak bangsa (Idi, 2014 : 25). Sedangkan di Thailand, perubahan kurikulum pendidikan nasional dari Kurikulum 2001 ke Kurikulum 2008, kurikulum tersebut 
merupakan suatu kebijakan pemerintah dalam mengembangkan nilai pendidikan lebih tinggi dan seimbang dengan kebutuhan masyarakat dunia kerja. Melalui pendidikan, diharapkan dapat menghapuskan kemiskinan dan pengajaran intelektual, serta berharap individual berpotensi dalam pendidikan sepanjang hayat dan bisa membimbing masyarakat berkualitas (Kantor Komite Pendidikan Nasional, $2002: 18)$.

Fatah Syukur mengatakan bahwa perubahan kurikulum dimulai dari konsepsional yang fundamental kemudian diikuti oleh perubahan strukturnya. Pada umumnya perubahan struktur kurikulum menyangkut beberapa komponen, yakni: 1) Perubahan tujuan kurikulum. 2) Perubahan isi dan struktur kurikulum. 3) Perubahan strategi kurikulum. 4) Perubahan sarana pendidikan. 5) Perubahan dalam sistem evaluasi kurikulum (Syukur, 2013 : 70).

Kurikulum merupakan komponen utama dalam pendidikan. Penentuan arah, isi, dan proses pendidikan merupakan bagian dari sebuah kurikulum yang pada akhirnya menentukan kualitas lulusan. Alasan ditetapkannya kurikulum 2013, agar peserta didik cakap pada kegiatan observasi, bertanya (wawancara), bernalar, dan berkomunikasi setelah mereka menerima materi pembelajaran. Hal tersebut didasarkan pada UU No.20 Tahun 2003 tentang sistem pendidikan nasional yaitu "Meningkatkan kualitas manusia Indonesia, yakni manusia yang beriman dan bertakwa kepada Tuhan Yang Maha Esa, berakhlak mulia, sehat, berilmu, cakap, kreatif, mandiri, dan menjadi warga Negara yang demokratis dan bertanggungjawab". Selain itu, perubahan kurikulum tidak hanya mengedepankan pada tiga aspek penilaian yaitu kognitif, afektif, dan psikomotorik, tetapi para peserta didik diharapkan mampu berperan aktif pada kegiatan pembelajaran.

Sebagai pembanding peneliti mengambil contoh kurikulum yang berada di Thailand, Penerapan Kurikulum Inti dalam UndangUndang Pendidikan Dasar Thailand Tahun 2551 (2008) bertujuan meningkatkan perilaku peserta didik yang lebih baik, serta memotivasi mereka belajar secara terus menerus. Ada beberapa aspek tujuan Pendidikan yang ditetapkan oleh pemerintah Thailand, yakni: 1) Bermoral, beretika, berpotensi, mempunyai harga diri, disiplin, menaati ajaran Buddha atau beriman sesuai dengan agama yang 
dianutkan, dan berprinsip pada Ekonomi Sederhana, 2) memiliki pengetahuan dan terampil dalam berkomunikasi, dapat memecahkan masalah, melek teknologi, dan mepunyai keterampilan, 3) Sehat jasmani dan rohani, ceria, dan menyenangi olahraga, 4) Cinta bangsa, bangga menjadi warga negara Thailand dan masyarakat dunia, serta berpartisipasi dalam pemerintahan demokratis dimana Raja sebagai simbol tertinggi, dan 5) Kesadaran dalam mengembangkan budaya Thai, menjaga dan melestarikan lingkungan alam, memberi manfaat dan kebaikan terhadp lingkungan, dan hidup dengan damai dan harmonis (Kementerian Pendidikan, $2010: 5$ ).

Pada perubahan kurikulum yang baru akan ditambahkan alokasi waktu proses pembelajaran dari 2 jam perminggu menjadi 3-4 jam perminggu serta ada alokasi waktu tambahan untuk menguatkan pendidikan Agama Islam agar peserta didik dapat mencapai dan memiliki tujuan kompetensi lulusan pembelajaran yang telah ditentukan oleh sekolah atau lembaga pendidikan secara lebih tinggi, disamping itu juga mengambil peran terhadap pendidik untuk memahami serta dapat menguasai kurikulum secara lebih baik, dengan melalui penerapan Rencana Pelaksanaan Pembelajaran (RPP) dan pelatihan guru untuk menerima perkembangan kurikulum.

Pendidikan agama Islam yang tercantum dalam kurikulum di Indonesia dan kurikulum 2008 di Thailand merupakan satu-satunya materi/mata pelajaran yang diterapkan kepada peserta didik pada setiap lapisan pendidikan dari SD hingga SMA. Kurikulum tersebut harus sesuai dengan tingkat jenjang pendidikan. Lebih-lebih lagi pada tingkat SMA, Pendidikan Agama Islam memiliki peran yang lebih signifikan.

Penentuan struktur kurikulum yang terdapat pada SMA/MA dilakukan melalui pemberian kesempatan peserta didik dmemilih Kelompok Peminatan, Lintas Minat, dan/atau pilihan Pendalaman Minat (Kementerian Pendidikan, 2010 : 5). Peserta didik dapat memiliki pilihan pendidikannya dengan mengikut keinginan dan butuhan mereka sendiri dalam melanjutkan kependidikannya, pada saat peserta didik lulus dari SMA. Mereka yang lebih tahu tentang keinginan dan kebutuhan yang akan dipilih jurusan masuk pada pendidikan di tingkat perguruan tinggi kelak nanti. 
Pendidikan agama Islam diberikan kepada peserta didik untuk mencapai kualitas agama Islam sebagai fondasi menjalankan printah agama sekaligus dapat mengamalkannya di masyarakat. Sebagaimana tujuan yang diinginkan oleh kurikulum PAI pada SMA yaitu; berpengetahuan, berpahaman terhadap materi pelajaran yang telah ditentukan dengan secara memdalam, berpotensi dalam analisis, sistensis, dan berpraktisi dengan baik, menjadi tauladan yang baik terhadap insan dengan berkreatif Islam, berfalsafah Islam, hidup mengikut ajaran Islam, bersyariat Islam, dan berprinsip pada ekonomi Islam. Berkarakteristik sebagai seorang muslim yang baik mengikut tauladan Nabi Muhammad SAW dan berpegan teguh pada al-Qur'an serta berpotensi dalam menyusunkan peristiwa-peristiwa yang berlaku dalam sejarah Islam supaya menjadi asas dalam kehidupan harian dan dalam pendidikan pada tingkat yang lebih tinggi (Kementerian Pendidikan, 2010 : 3). Dari ragam kurikulum yang ada, pemerintahlah yang memiliki kekuasaan terhadap pendidikan negara yang bertugas untuk menganalisis dan meneliti tentang kurikulum pendidikan agama Islam serta bisa mengambil kebijakan dalam mengatur standar kebijakan pendidikan Nasional.

Berdasarkan uraian di atas, peneliti mengidentifikasi beberapa masalah, di antaranya: (1) Kurikulum sering berubah-ubah mengikuti situasi dan kondisi era globalisasi; (2) Kurikulum hanya menekankan pada aspek kognitif tetapi psikomotorik dan afektif masih kurang diterapkan; (3) Pelaksanaan proses pembelajaran masih berpusat pada guru serta dokumen dianggap belum rinci, sehingga pengembangan kurikulum disekolah belum harmoni dengan esensi kurikulum induk; (4) Guru sebagai pendidik masih berpegan pada kurikulum tradisional yang tidak berani untuk berkembang mengikut perubahan dunia pendidikan; (5) guru belum mampu melaksanakan tugasnya sesuai dengan tuntutan aturan perundangan, terutama menyangkut kinerja dan kompetensi; serta (6) Minimnya dukungan tenaga akademik dalam pengembangan kurikulum sekolah.

\section{Definisi Kurikulum}

Istilah "kurikulum" memiliki banyak arti yang beragam, banyak pakar pendidikan yang mendefiniskan kurikulum. Kurikulum berasal dari bahasa Latin yaitu "curriculer" yang berarti jarak lurus 
yang harus dilalui oleh pelajar (Hamalik, 2013 : 16). Dalam bahasa Arab, kata kurikulum diidentikkan dengan kata “ مَنهَجْ وَمِنْهَاجْ

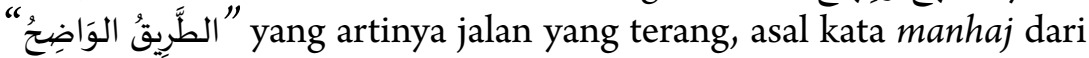

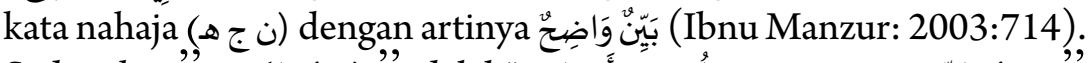

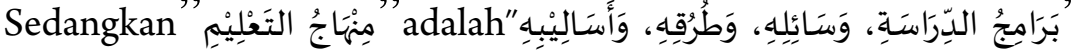
yang bermaksudnya; Program studi, cara, metode dan tekniknya (Ahmad Muktar: 1933:2556). Sebagaimana pada kata “"مِنْهَاج" "Un" tersebut terdapat dalam Surat Al-Maidah ayat 48 yang artinya: "Untuk setiap umat diantara kamu, kami berikan aturan dan jalan yang terang" (Q.S. Al -Maidah: 48).

Kata "Al-Manhaj" pada ayat di tersebut, Ibnu katsir menafsirkan sebagai jalan, landasan, dan jalur yang terang lagi mudah"(Kasir, 1979 : 588). Suatu perjalanan tentunya tidak akan berjalan dengan mulus tanpa adanya rencana, susunan, dan metode sebagai pedoman. Pendidikan tidak dapat terlaksana dengan baik tanpa adanya sistem dan kurikulum yang baik pula. Oleh karena itu kurikulum merupakan pedoman dalam melaksanakan pendidikan secara terus menerus. Bagi orang awam, kurikulum diartikan sebagai kumpulan mata pelajaran atau sejumlah mata pelajaran atau disiplin ilmu tertentu yang akan didapat peserta didik, seperti kurikulum pendidikan Agama, Bahasa, IPA, IPS, yang harus diajarkan di sekolah.

Oemar Hamalik mendefinisikan kurikulum merupakan seperangkat rencana dan aturan mengenai isi dan bahan pembelajaran serta metode yang dipakai dalam sebuah proses belajar mengajar. Kurikulum terdiri dari susunan, bahan kajian dan pelajaran dalam mencapai tujuan penyelenggaraan satuan pendidikan nasional (Hamalik, 2013 : 18; Zakiah Daradjat, 2012 : 122). Fauzan mengemukakan, Kurikulum sendiri memiliki dua sisi penting, yaitu: 1) kurikulum sebagai suatu dokumen, dan 2) kurikulum dalam ranah implementasi (Fauzan, 2017 : 38). Kurikulum sebagai dokumen berfungsi menjadi pedoman bagi guru, sementara posisi kurikulum sebagai ranah implmentasi, dipahami sebagai penerapan dokumen ke dalam praktik pembelajaran di kelas. Dengan demikian kurikulum dipahami sebagai pedoman yang memiliki isi/bahan pelajaran, tujuan, kegiatan, sistem pengukuran secara terstruktur untuk mencapai tujuan yang sudah ditentukan. 
Menurut Mahir Ismail salah satu dari ahli pendidikan dari Mesir berpandangan tentang kurikulum bahwa: "the education curriculum is divided into two definitions, namely narrow and broad terms. Understanding the education curriculum narrowly is a comprehensive plan in the teaching and learning process. Teaching and learning to perfect the needs of students in class or at the level of education that has been formally determined by educational institutions. While the broad understanding of the education curriculum is a written document that includes a comprehensive plan for various groups of teaching and learning processes (knowledge, attitudes, skills) obtained by students in the class or at certain levels of education, inside or outside the formal educational institution" (Ismail, $2016: 13$ ).

S. Nasution juga mengemukakan bahwa kurikulum ditafsirkan sebagai berikut: (a) kurikulum sebagai rancangan program, segala hal yang dipersiapkan pihak sekolah dalam mendukung aktifitas pembelajaran; (b) kurikulum sebagai hal-hal yang diharapkan dapat dipelajari siswa meliputi aspek penguatan sikap, pengetahuan, dan keterampilan; dan (c) kurikulum sebagai pengalaman siswa, bentuk ekspresi atau hal baru yang muncul dalam kegiatan pembelajaran (Nasution, $2003: 5$ ).

Menurut Nana Syaodih Sukmadina, sedikitnya ada tiga bagian dalam konsep kurikulum, yaitu kurikulum sebagai sistem, substansi, dan sebagai bidang studi. Adapun penjalasan dari tiga kosep tersebut ialah: Pertama, kurikulum sebagai suatu sistem, yakni suatu sistem kurikulum yang menjadi bagian dari sistem persekolahan, sistem pendidikan, dan sistem masyarakat. Kedua sebagai substansi, adalah kurikulum yang dipandang sebagai suatu rencana kegiatan belajar siswa, atau sebagai perangkat tujuan yang akan dicapai. Ketiga, sebagai bidang studi, yakni kumpulan materi pelajaran yang didasarkan pada rumpun keilmuan (Sukmadinata, 2016 : 27). Maka dalam pandangan dari Mahir, Nasution dan Nana Syaodih bahwa kurikulum sesuai mencakup meteri/bahan ajar, produk, proses, dan praksis, sistem, program pendidikan yang ada di kelas atau luarnya di lembaga pendidikan (sekolah) yang bertujuan untuk menanamkan pengalaman kepada peserta didik semaksimalnya.

Berdasarkan konsep di atas dapat penulis simpulkan bahwa kurikulum adalah program pendidikan yang memiliki sistem, 
target tujuan, materi/bahan pembelajaran, metode, sistem evaluasi pembelajaran yang direncanakan dan dilaksanakan oleh pendidik dan lembaga pendidikan kepada peserta didik secara formal dan nonformal. Sedangkan hasil dari implementasi kurikulum tergantung kepada kebijakan pendidik, kepala sekolah, tenaga kependidikan dan satuan lembaga pendidikan, oleh karena mereka adalah orang yang paling berperan dalam menyusun dan melaksanakan kurikulum.

\section{Posisi Kurikulum dalam Pendidikan}

Kurikulum berperan sangat strategis dalam pendidikan formal karena keberadaannya menghubungkan sebuah idealisme cita-cita pendidikan dengan kenyataan atau Pratik pendidikan yang mengarah pada sebuah pencapaian tujuan (Fauzan, 2017 : 11). Selain komponen pendidik dan peserta didik, kurikulum merupakan komponen penting dalam sistem pendidikan. Keberadaan kurikulum menjadi hal yang paling substansial, posisinya dapat menentukan arah tujuan pendidikan. Secara umum, kurikulum berisi pedoman tentang aspek tujuan, konten isi mata pelajaran, proses pembelajaran, dan evaluasi pembelajaran. Keberadaan menjadi sangat strategis posisinya, karena komponen kurikulum dapat menjawab tingkat keberhasilan pendidikan, terutama menyangkut proses dan hasil akhir proses pembelajaran. Bagi Wichai Wongyai seorang ahli pendidikan dari Thailand, mengatakan bahwa the importance of the curriculum is to build state education at every level of education, from the level of kindergarten (TK), elementary school (SD), secondary school, non-formal education, professional education, and at the college level. Both the educational curriculum is in short learning time and a long time. The curriculum as an instrument in carrying out the learning process for the State to have quality education (Wongyai, 2011 : 7). Di antara kepentingannya ialah; 1) Kurikulum adalah asas dan landasan dalam merencanakan kerangka akademik, menyusun Rencana Pelaksanaan Pembelajaran (RPP), manajemen pembelajaran, memilih dan mengembangkan tenaga kependidikan, menyiapkan sarana, menginovasikan pendidikan, mengajar, pembiayaan, dan bangunan. Ini adalah kepentingan yang sesuai dan setara dengan tujuan kurikulum. 2) Kurikulum sebagai rancangan dan landasan bagi pendidikan nasional untuk menghasilkan tujuan dan kebijakan pendidikan. 3) Kurikulum sebagai instrumen dalam mengawasi 
standar pembelajaran pada setiap lembaga pendidikan dan kualitas peserta didik, hal itu mengikuti kebijakan dan rancangan pendidikan nasional dan sesuai dengan tuntutan pada setiap daerah. 4) Sistem kurikulum akan menentukan tujuan, isi mata pelajaran, metode, pengalaman, belajar-mengajar, sumber daya, dan evaluasi proses pembelajaran untuk guru dan pengelolanya. 5) Kurikulum sebagai instrumen yang menentukan kualitas pengembangan sumber daya manusia serta seimbang dengan perkembangan masyarakat negara.

Keberhasilan proses Pendidikan bergantung pada kurikulum, yakni sebagai alat dan pedoman dalam pelakasanaan pendidikan, artinya tanpa kurikulum yang baik dan tepat maka tujuan dan sasaran pendidikan akan sulit tercapai sesuai dengan sasaran pendidikan yang dicita-citakan (Saepudin, 2013 29-47; Fauzan, 2017 : 11). Posisi dan peran kurikulum yang central tersebut yang menyebabkan kurikulum selalu menjadi fokus utama dalam setiap perubahan sistem pendidikan.

Berdasarkan beberapa pandangan tersebut disimpulkan bahwa posisi kurikulum merupakan suatu komponen dalam sistem pendidikan formal yang di dalamnya terdapat rencana pembelajaran yang dibuat oleh guru sebagai acuan dalam proses pembelajaran. Adanya rencana pembelajaran tersebut menjadikan guru memiliki kesiapan pribadi dan kemampuan sesuai dengan kebutuhan masyarakat. Oleh sebab itu dalam kurikulum bukan hanya merumuskan tentang tujuan yang harus dicapai, atau bukan sekadar rangkaian ilmu pengetahuan yang diajarkan dalam kelas, tetapi juga memberikan pemahaman tentang pengaruh proses belajar mengajar yang harus dimiliki setiap siswa. Maka peran kurikulum sangat penting dalam pengembangan proses pembelajaran pada setiap waktu, tempat dan jenjang pendidikan.

\section{Landasan Pengembangan kurikulum.}

Ada empat landasan yang menjadi acuan dalam mengembangkan kurikulum sebagaimana yang dijelaskan oleh Syaodih yakni: landasan filosofis, landasan psikologis, landasan sosial, dan landasan pengembangan ilmu pengetahuan dan teknologi (Sukmadinata, 2016 : 38). Landasan pertama filosofis; falsafat merupakan strategi dalam menentukan dan meningkatkan dalam 
suatu kebijakan. Nana Syaodih dan Abdullah Idi menyatakan bahwa filsafat merupakan upaya dalam menggambarkan dan menyatakan suatu pendangan secara sistematis dan komprehensif tentang alam semesta dan kedudukan manusia didalamnya (Sukmadinata, 2016 : 39; Abdullah Idi, 2014 : 59-60). Filsafat membahas seluruh permasalahan manusia termasuk pendidikan yang biasa kita sebut dengan filsafat pendidikan.

Landasan kedua, psikologis: pada proses pendidikan terdapat interaksi antara individu manusia, yakni antara pendidik dengan peserta didik dan peserta didik dengan masyarakat. Pada interaksi induvidu manusia, ketahuilah bahwa manusia itu berbeda, berbeda pikiran, prasaan, keinginan, fisik dan juga prilaku mereka. Oleh karena itu kondisi psikologi mereka berbeda. Menurut Nana Syaodih bahwa "kondisi psikologi merupakan karakteristik psiko-fisik seseorang sebagai individu, yang dinyatakan dalam berbagai bentuk perilaku dalam interaksi dengan lingkungannya" (Sukmadinata, 2016 : 45). Landasan psikologi merupakan satu landasan yang menjadi ukuran dalam mengambil pertimbang terhadap suatu kurikulum pendidikan.

Landasan ketiga, landasan sosial. Dalam proses pengembangan kurikulum, perubahan masyarakat menjadi dasar pijakan utama. Keberadaan kurikulum sudah selayaknya beradaptasi dengan kebutuhan masyarakat. Prinsip dasar sebuah kurikulum harus mencerminkan keinginan, cita-cita, dan kebutuhan masyarakat. Secara alamiah di masyarakat sering kali terjadi konflik, masalah, dan menunjukan bahwa ada sesuatu kesalahan di dalamnya, baik berupa individu maupun golongan.

Landasan keempat, landasan perkembangan ilmu pengetahuan dan teknologi; pengembangan ilmu pengetahuan merupakan perubahan secara dinamis terhadap masyarakat dan dunia pendidikan. Sejak dulu hingga sekarang, teknologi menjadi bagian penting bagi manusia sehingga menjadi salah satu kebutuhan, sehingga penggunaan alat dan akal (hardware dan software) menjadi hal yang lumrah, hal tersebut membuat anggota tubuh, pancaindra, dan otak manusia lebih kuat (Sukmadinata, $2016: 67$ ).

Menurut pendapat Oemar Hamalik (2013:33) bahwa landasan pengembangan kurikulum terdiri dari: a) Filsafat pendidikan; b) 
Lingkungan; c) Kebutuhan pembangunan tersirat dalam tujuan pendidikan nasional; d) Perkembangan Ilmu pengetahuan dan teknologi. Selanjutnya, Abdullah Idi mengatakan bahwa asas-asas (landasan) perkembangan kurikulum terdiri dari: a) Asas Filosofis; b) asas sosiologi; c) asas psikologi; dan d) asas organisatoris (Abdullah Idi, 2014 : 59). Bagi Mohamad Ansyar landasan kurikulum terbagi menjadi pengaruh meliputi empat fondasi utama terdiri dari beberapa landasan: a) filosofis, b) historis, c) sosiologis, dan d) psikologis (Mohamad Ansyar, 2015 : 61).

Berdasarkan pandangan dari beberapa ahli pendidikan, disimpulkan bahwa secara umum pengembangan kurikulum didasarkan pada beberapa aspek, yakni (1) aspek filsafat, baik dari pemikiran para tokoh filsafat, maupun dasar filsafat sebuah negara (national philoshopy). (2) dasar psikologi, terutama menyangkut aspek psikologi perkembangan dan psikologi pendidikan. (3) sosial budaya, hal ini terkait dengan aspek perubahan dan kebutuhan masyakat luas; dan (4) landasan perkembangan ilmu pengetahuan dan teknologi, terutama terkait dengan penyesuaian kurikulum dengan perkembangan ilmu pengetahuan dan teknologi.

\section{Komponen Kurikulum}

Komponen yang ada pada kurikulum saling berkaitan satu sama lain, meliputi: tujuan kurikulum, isi, metode, dan sistem evaluasi (penilaian) kurikulum (Sukmadinata, 2016:3). Penjelasannya secara lebih detail sebagai yang berikut:

\section{a. Tujuan Kurikulum}

Mengembangkan ilmu tentang kurikulum dan sistem kurikulum merupakan tujuan kurikulum (Majid, 2014 : 3). Sedangkan Oemar Hamalik berpendapat bahwa tujuan kurikulum adalah tujuan yang hendak dicapai oleh suatu program studi, bidang studi dan suatu mata ajaran yang disusun berdasar tujuan intitusional (Hamalik, 2013 : 6; Gunawan, 2014 : 6). Adapun Wicha Wongyai mengatakan bahwa the purpose of the curriculum is the quality of students after graduating from the level of education, which can master it such as subject matter, skills in the learning process, creative and characteristic, the desired values (Wongyai, 2011 : 7). Sementara tujuan pendidikan nasional RI ialah 
seperti yang tercantum dalam UU No. 20 Tahun 2003 tentang sistem pendidikan nasional.

Ada dua jenis tujuan yang terkandung dalam kurikulum suatu sekolah, sesuai dengan pendapat Zakiah Darajat yaitu; a) Tujuan utama yang ingin dicapai sekolah. b) Tujuan yang ingin dicapai dalam setiap mata pelajaran bidang studi. Dengan maksud bahwa tujuan yang ingin dicapai oleh sekolah adalah tujuan yang sudah ditetapkan oleh sekolah atau lembaga pendidikan terhadap proses pembelajaran secara umum, termasuk semua standar-standar dan fasilitas yang bertanggung jawab dalam mencapai tujuan lembaga pendidikan, sedangkan tujuan yang ingin dicapai dalam setiap mata pelajaran atau bidang studi adalah untuk menggambarkan dalam bentuk pengetahuan. keterampilan dan sikap yang diharapkan dapat dimiliki oleh peserta didik setelah mempelajari suatu bidang studi pada suatu sekolah atau lembaga pendidikan tertentu (Zakiah Daradjat, 2012 : 123).

Dari beberapa definisi di atas dapat disimpulkan bahwa tujuan kurikulum pendidikan adalah untuk membentuk peserta didik mencapai tujuan pendidikan pada proses belajar mengajar baik pada aspek kognitif, afektif, dan psikomotorik.

\section{b. Isi Kurikulum atau materi pelajaran}

Wichai Wongyai mengatakan bahwa curriculum material is the content of the lessons, scientific knowledge and learning experiences that must be learned for students to follow in order so that students know, competent to follow the educational curriculum goals that have been set (Wongyai, 2011 : 8). Abdullah Idi menjelaskan bahwa isi atau materi merupakan materi yang diprogramkan untuk mencapaikan tujuan pendidikan yang telah ditetapkan. Isi atau materi yang dimaksud biasanya berupa materi bidang-bidang studi seperti; Bahasa Indonesia, Matematika, Ilmu Pengetahuan Alam, Ilmu Pengetahuan Sosial, Akidah Akhlak, Fiqih, Al-Quran Hadis, Bahasa Arab, dan lainnya (Abdullah Idi, 2014 : 38). Sedangkan bagi Mohamad Ansyar mengatakan Isi atau konten kurikulum adalah mata pelajaran (subject matters), pengetahuan, pengalaman belajar (learning experiences) atau informasi (Mohamad Ansyar, 2015 : 342).

Dari penjelasan di atas bahwa isi kurikulum merupakan materi pelajaran atau bahan ajar yang tersusun yang ingin dicapai 
oleh pendidik kepada peserta didik melalui proses pembelajaran yang terintergrasi dari ranah pengetahuan, sikap dan keterampilan. Melalui proses pembelajaran yang mengintegrasikan ketiga ranah tersebut dalam proses pembelajaran akan membentuk pengetahuan, pengalaman, dan kompetensi siswa. Sekolah umum maupun madrasah, baik swasta maupun negeri pasti mendapatkan pembelajaran Pendidikan Agama Islam. Isi kurikulum yang diberikan diatur dalam bentuk kelompok mata pelajaran. Pada struktur program sekolah umum, Pendidikan Agama Islam meliputi beberapa unsur, yaitu al-Qur'an, Hadis, Fiqh, Tauhid, Akhlak, Syariah. dan Sejarah Islam (Marliana, 2013 : 137-160). Pada kurikulum Pendidikan Agama Islam 2008 di Thailand dalam isi mata pelajaran termasuk juga mata pelajaran bahasa Arab dan bahasa Melayu (Kementerian Pendidikan, $2010: 8$ ).

Isi kurikulum merupakan bahan kajian dan pelajaran yang meliputi kompetensi-kompetensi, indikator dalam mencapai tujuan pembelajaran sesuai dengan tujuan pendidikan nasional. Pendidik dan peserta didik harus berpartisipasi dalam proses pembelajaran dengan sebanyak mungkin serta melaksanakan pembelajaran sesuai dengan kebutuhan dan minat peserta didik yang berpedoman pada standar dan kompetensi pembelajaran yang telah dirumuskan dalam kurikulum.

\section{c. Metode/Proses Pembelajaran}

Metode adalah satu komponen penting pada kurikulum dalam memindahkan suatu isi atau bahan pelajaran dari pendidik, sumber-sumber ilmu, dan lingkungan umum kepada peserta didik. Oemar Hamalik \& Heri Gunawan mengatakan bahwa metode kurikulum adalah cara yang cepat dan tepat dalam mengajar atau menyampaikan mata pelajaran kepada siswa supaya menyampai tujuan yang ditentukan (Hamalik, 2013 : 26; Gunawan, 2014 : 55).

Dalam proses pembelajaran dimiliki beberapa macam pendekatan (approach) dalam menerapkan proses belajar mengajar oleh guru kepada siswa seperti; pendekatan kontesktual, pendekatan ilmiah, pendekatan berpusat pada siswa, pendekatan berpusat pada guru dan sebagainya.

Untuk menguatkan pelaksanan proses pembelajaran, Mulyasa mengatakan sedikitnya mencakup tiga hal dalam pelaksanaan proses 
pembelajaran di sekolah, yakni: pre tes, pembentukan kompetensi, dan post test. Dalam menyampaikan sebuah mata pelajaran, seharusnya menpunyai sarana dan prasarana pendidikan yang baik untuk memudahkan dalam menyampai isi mata pelajaran (Mulyasa, $2006: 255)$.

Dengan ini dapat disimpulkan bahwa beberapa metode dan proses kurikulum yang digunakan pada umumnya adalah pendekatan ceramah atau seminar, diskusi, hafalan, ilmiah, dan pembelajaran yang bersifat tekstual. Tapi setiap kali pendidik ingin menerapkan proses pembelajaran, pendidik harus memiliki ide dalam mengunakan metode yang sesuai dengan situasi peserta didik, waktu dan sekolah.

\section{d. Evaluasi Kurikulum}

Untuk didapatkan sebuah informasi tentang keberhasilan sebuah kurikulum pendidikan diharuskan mengadakan evaluasi. Evaluasi sebagai salah satu pendekatan untuk mendapatkan informasi dari pengukuran proses pembelajaran. Seperti yang didefinisikan oleh Wichai bahwa "evaluation is the process of examining and evaluating the quality of students after completion of learning activities, evaluating the quality of learning activities in accordance and balanced with the objectives and subject matter formulated in the curriculum" (Wongyai, $2011: 8)$.

Dalam evaluasi sangat penting tidak hanya untuk memperlihatkan hasil sejauh mana tingkat prestasi anak didik, tapi juga menjadi suatu sumber input dalam upaya perbaikan dan pembaruan suatu kurikulum. oleh karena pendidikan bukan hanya guru di kelas sendiri yang semata bertanggung jawab, bahkan kesemua pihak yang berkaitan dengan pendidikan, baik guru, orang tua dan masyarakat. Arifin mengatakan bahwa hasil yang didapat dart evaluasi dapat dijadikan feed back (balikan) dalam menyempurnakan kurikulum dan pembelajaran oleh guru (Arifin, 2014 : 268).

Kegiatan evaluasi memberikan berbagai informasi terkait kurikulum dan pembelajaran, administrator pendidikan dan sekolah, fasilitas pendukung media, alat bantu belajar dan berbagai informasi tentang perbaikan kurikulum, pembelajaran dan manajemen serta akuntabilitas pendidikan pada seterusnya. Sebagaimana dikemukakan oleh Wright dalam kutipan Sukmadinata bahwa "curriculum evaluation 
may be defined as the estimation of growth and progress of students toward objectives or values of the curriculum" (Sukmadinata, 2016:173).

Beberapa jenis-jenis evaluasi yang dapat diterapkan dalam menilaikan hasil belajar bagi guru untuk berpedoman pada proses belajar mengajar (Kementerian Pendidikan, 2010 : 141-143) seperti: evaluasi diskusi antara individual, evaluasi kinerja (performance), evaluasi otentik (authetic assessment), dan evaluasi portofolio. Hasilhasil evaluasi atau nilai belajar dapat digunakan oleh guru, kepala sekolah dan pelaksana pendidikan lainnya dan membantu dalam meningkatkan kualitas peserta didik, memilih bahan ajar, metode dan media pembelajaran, cara mengevaluasi serta fasilitas pendidikan lainnya (Sukmadinata, 2016 : 17). Melalui penerapan kurikulum tersebut, diharapkan pendidikan ke depan akan lebih meningkatkan dan berkualitas.

\section{Pendidikan Agama Islam Tingkat SMA}

Pendidikan Agama Islam (PAI) merupakan pendidikan yang berkaitan dengan pembentukan spiritual dan karakter positif (akhlak al-karimah) peserta didik. PAI adalah suatu aktivitas atau usaha-usaha tindakan dan bimbingan yang dilakukan secara sadar dan sengaja serta terencana yang mengarah pada terbentuknya kepribadian anak didik yang sesuai dengan norma-norma yang ditentukan oleh ajaran agama Islam (Nata, 2012 : 179; Tafsir, 2014 : 12). Sementara pendidikan agama merupakan salah satu mata pelajaran yang dianggap paling terdepan dalam urusan pembentukan karakter peserta didik karena sejak kehadirannya telah mengusung misi pembentukan akhlak mulia yang ujungnya membentukan karakter peserta didik.

Secara umum, Pendidikan Agama Islam (PAI) di SMA merupakan mata pelajaran yang terdiri dari: al-Qur'an, hadis, aqidah, akhlak, fiqih, dan sejarah kebudayaan Islam. Pada mata pelajaran ini juga tidak diajarkan dan dikembangkan hanya pada SMA bahkan juga dikembangkan pada Jenjang Pendidikan Dasar. Melalui pembelajaran PAI, siswa diajarkan aqidah sebagai dasar/pondasi keimanannya, alQur'an dan hadis sebagai pedoman/pegangan hidupnya, fiqih sebagai landasan hukum dalam beribadah, sejarah Islam sebagai pembelajaran terhadap keteladanan rasulullah dan orang-orang alim terdahulu, dan akhlak sebagai pedoman manusia berperilaku dalam berinteraksi 
dengan masyarakat. Oleh sebab itu, tujuan utama dari Pembelajaran PAI adalah pembentukan karakter/kepribadian siswa yang tercermin dalam tingkah laku dan pola pikirnya dalam kehidupan sehari-harinya. Penerapan meroe pembelajaran yang tepat akan menghasilkan nilai yang baik bagi siswa, baik dari sisi evaluasi pembelajaran maupun karakter (Ainiyah, 2013 : 25-58).

Dalam kontek Thailand, Pendidikan Agama Islam sudah mulai dimasukan pada sekolah pemerintah pada tahun 1975 secara kesinambungan. Untuk sekolah negeri, Pendidikan Agama Islam merupakan suatu mata pelajaran agama Islam yang tercatum dalam kelompok mata pelajaran ilmu sosial, agama, dan kebudayaan, yang diterapkan pada sekolah umum yang berdasarkan pada kurikulum inti pendidikan dasar 2008. (Kementerian Pendidikan, 1999 : 3). Sedangkan di sekolah swasta umum yang memiliki bidang pendidikan agama Islam, pendidikan agama Islam merupakan mata pelajaran secara mandiri, baik mata pelajaran itu berupa terpisah diantara mata-mata pelajara yaitu; mata pelajaran al-qu'ran, hadis, tauhid, fiqih, sejarah, akhlak, atau dalam berbentuk terpadu yang bergantung kepada kesiapan sekolah atau lembaga pendidikan.

Sementara di Indonesia, penerapan mata pelajaran Pendidikan Agama Islam terbagi menjadi dua bagian kebijakan, yakni (1) kebijakan oleh Kementerian Pendidikan. Pendidikan Agama Islam sebagai mata pelajaran wajib untuk semua satuan pendidikan katagori Sekolah Dasar (SD), Sekolah Menengah Pertama (SMP), dan Sekolah Menengah Umum (SMU), Sekolah Menengah Kejuruan (SMK). Untuk satuan pendidikan tersebut, Pendidikan Agama Islam disampaikan secara terintegrasi. (2) kebijakan oleh Kementerian Agama. Mata pelajaran Pendidikan Agama Islam untuk semua tingkatan madrasah, meliputi Madrasah Ibtidaiyah (MI), Madrasah Tsanawiyah (MTs), dan Madrasah Aliyah (MA). Pendidikan Agama Islam pada satuan pendidikan tersebut diajarkan secara terpisah meliputi, yaitu al-Quran, hadis, akidah, akhlak, dan sejarah kebudayaan Islam.

Penelitian ini merupakan penelitian kualitatif (Qualitative research), Jenis metode penelitian ini bersifat deskriptif kualitatif, yaitu metode penelitian yang bertujuan untuk menggambarkan atau menjelaskan secara sistematis dan mendalam tentang realitas sosial 
dan berbagai fenomena yang terjadi dimasyarakat yang menjadi subjek penelitian (Sugiyono, 2013 : 47). Sedangkan pendekatan yang digunakan merupakan kajian pustaka (literature review), Adapun sumber data dalam penelitian yang terdapat yaitu: a) Data primer; yakni berupa dokumen kurikulum Pendidikan Agama Islam 2013 dan kurikulum Pendidikan Agama Islam 2008, buku pembelajaran pendidikan agama Islam, dan buku-buku yang berkaitan dengan kebijakan kurikulum tersebut, b) Data sekunder; yakni hasil dari wawancara dengan para ahli pendidikan agama Islam dan kurikulum sebagai narasumber tambahan untuk menguatkan pada data primer.

\section{B. Pembahasan}

Penelitian ini berisi kajian tentang Kebijakan Kurikulum Pendidikan Agama Islam (PAI) yang dikeluarkan oleh Pemerintah negara dalam berupaya meningkatkan kualitas rakyat sebagai sumber daya manusia dengan melalui pendidikan. Kebijakan perubahan kurikulum merupakan politik pendidikan yang berkaitan dengan kepentingan berbagai pihak. Pada pendidikan Nasional setiap Negara memiliki tujuan tertentu dalam melaksanakan dan meningkatkan kualitas pendidikan masing-masing yang merupakan jawaban kepada perubahan zaman dan masyarakat. Oleh karena itu, yang bertanggungjawab tentang kurikulum harus melaksanakan dengan sebaik-baiknya dengan melalui belajar, berpamahamam dalam menerapkan kurikulum sesuai dengan tugas masing-masing secara optimal.

\section{Kebijakan penerapan PAI pada Kurikulum}

Kurikulum 2013 merupakan pengembangan lanjutan dari kurikulum sebelumnya (KBK dan KTSP) yang mencakup kompetensi sikap, pengetahuan, dan keterampilan secara terpadu. Dalam penelitian ini, menyatakan bahwa Pendidikan Agama Islam (PAI) merupakan salah datu mata pelajaran yang di sekolah yang diterapkan oleh pemerintah Indonesia dan Thailand. Kurikulum PAI Indonesia berdasarkan pada UU No. 20 Tahun 2003 Pasal 1 Ayat 19 yakni seperangkat rencana dan pengaturan mengenai tujuan, isi, dan bahan pelajaran serta cara yang digunakan sebagai pedoman penyelenggaraan kegiatan pembelajaran untuk mencapai tujuan 
pendidikan tertentu. Selain itu pada PP No. 55 Tahun 2007 bahwa Pendidikan agama dan keagamaan menjelaskan bahwa pendidikan agama berfungsi membentuk manusia Indonesia yang beriman dan bertakwa kepada Tuhan Yang Maha Esa dan berakhlak mulia serta mampu menjaga kedamaian dan kerukunan hubungan inter dan antar umat beragama. Pendidikan agama bertujuan untuk mengembangkan kemampuan peserta didik dalam memahami, menghayati, dan mengamalkan nilai-nilai agama serta menyelaraskan penguasaan dalam ilmu pengetahuan, teknologi dan seni. Mengacu pada UU dan PP di atas, maka setiap satuan pendidikan pada semua jalur, jenjang, dan jenis pendidikan wajib menyelenggarakan pendidikan agama.

Pada kondisi di Thailand, pemerintah negara menginginkan rakyat mendapatkan pendidikan yang baik, kualitas hidup tinggi serta hidup aman dan damai di masyarakat dengan berdasarkan pada Undang-Undang Pendidikan negara tahun 1999 dan ditambahkan (Edisi 2) Tahun 2002 pada pasal 6 dengan mengungkapkan bahwa pendidikan merupakan proses pembelajaran untuk mengembangkan individual dan masyarakat dengan mengtranspotasi ilmu pengetahuan, berlatih, berkrusus, berwarisi budaya, memperkembangkan ilmu akadimik, menciptakan pengentahun dan sarana yang terdapat dari lingkungan, membangun masyarakat dengan ilmu pengetahuan serta dapat kependidikan sepanjang hidup, disamping mengembangkan rakyat Thai menjadi orang yang sempurna, baik pada fisik, spiritual, moral, pengetahuan dan etika, berakhlak dan berbudaya dalam kehidupan harian serta bisa hidup bersama dimasyarakat secara damai dan harmonis.

Berdasarkan Undang-Undang tersebut, maka melahirkan kebijakan dalam mengembangkan dan memasukan Pembelajaran Pendidikan Agama Islam ke dalam kurikulum pendidikan nasional. Kerena PAI merupakan salah satu kebutuhan masyarakat muslim yang bagi pemerintah harus ambil peranan dengan membuat timbangan demi menghasilkan rakyat penduduk yang berkualitas. Maka pada kebijakan pemerintah disini adalah menentukan konsep, tujuan, strategi, prinsip kurikulum PAI secara lebih khusus seperti yang telah disajikan pada temuan penelitian diatas baik di Indonesia maupun di Thailand. 
Dalam penelitian ini ditemukan perbedaan dan persamaan antara kurikulum Indonesia dan Thailand. Sebagaimana dijelaskan melalui Tabel 1.

\section{Tabel 1. Analisis Kebijakan Penerapan Kurikulum Indonesia Thailand}

\begin{tabular}{|c|c|c|}
\hline Indikator & Kurikulum 2008 & Kurikulum 2013 \\
\hline $\begin{array}{l}\text { K o n s e p } \\
\text { Kurikulum }\end{array}$ & $\begin{array}{l}\text { Berdasarkan UU Tahun } 1999 \\
\text { dan edisi } 2002 \text { pasal } 6 . \text { Surat } \\
\text { keputusan kementerian no. } \\
\text { 293/2551, dan surat keputusan } \\
\text { kementerian pendidikan dasar } \\
\text { tanggal 19/4/ } 2553\end{array}$ & $\begin{array}{l}\text { Sesuai aturan Undang-undang No. } 20 \\
\text { Tahun 2003. Pasal 1, 35, 36, } 157 \text { dan } \\
\text { PP No. } 55 \text { Tahun 2007. Keduanya } \\
\text { merupakan landasan tentang Sistem } \\
\text { Pendidikan Nasional dan Pendidikan } \\
\text { Agama dan Keagamaan. }\end{array}$ \\
\hline $\begin{array}{l}\text { S t rategi } \\
\text { Penerapan } \\
\text { Kurikulum }\end{array}$ & $\begin{array}{l}\text { Bermula dilaksanakan pada } \\
\text { tahun akademik 2009/2010 } \\
\text { pada semua jenjang kelas dan } \\
\text { ada sebagian diterapkan secara } \\
\text { bertahap-tehapan menurut } \\
\text { kebijakan sekolah }\end{array}$ & $\begin{array}{l}\text { Dimulai pada tahun akademik } \\
2013 / 2014 \text { yang diterapkan pada } \\
\text { sebagian sekolah, secara bertahap. }\end{array}$ \\
\hline Prinsip & $\begin{array}{l}\text { 1) Kurikulum pendidikan } \\
\text { untuk persatuan bangsa, } \\
\text { 2) Kurikulum Pendidikan yang } \\
\text { Universal, } \\
\text { 3) Kurikulum desentralisasi } \\
\text { otoritas dan kebutuhan lokal } \\
\text { setempat, } \\
\text { 4) Kurikulum cukup } \\
\text { fleksibilitas. } \\
\text { 5) Kurikulum yang berpusat } \\
\text { pada peserta didik (student } \\
\text { centered.) } \\
\text { 6) Kurikulum ditujukan untuk } \\
\text { seluruh pendidikan formal, } \\
\text { non-formal dan informal. }\end{array}$ & $\begin{array}{l}\text { 1) Kurikulum satuan pendidikan } \\
\text { 2) Standar kompetensi lulusan (SKL) } \\
\text { ditetapkan pada seluruh satuan } \\
\text { pendidikan, jenjang pendidikan, dan } \\
\text { program pendidikan. } \\
\text { 3) Kurikulum berbasis kompetensi } \\
\text { (KBK) meliputi aspek sikap, } \\
\text { pengetahuan, dan pengetahuan. } \\
\text { 4) Kurikulum memberikan } \\
\text { kesempatan kepada peserta didik } \\
\text { untuk lebih aktif, } \\
\text { 5) Kurikulum berpusat pada potensi, } \\
\text { 6) Kurikulum berdasar } \\
\text { pada perkembangan ilmu } \\
\text { pengetahuan, dan teknologi. } \\
\text { 7) Kurikulum beradaptasi dengan } \\
\text { kebutuhan hidup. } \\
\text { 8) Kurikulum membangun } \\
\text { kehidupan masyarakat, bangsa dan } \\
\text { negara. }\end{array}$ \\
\hline
\end{tabular}




\begin{tabular}{|c|c|}
\hline Tujuan & 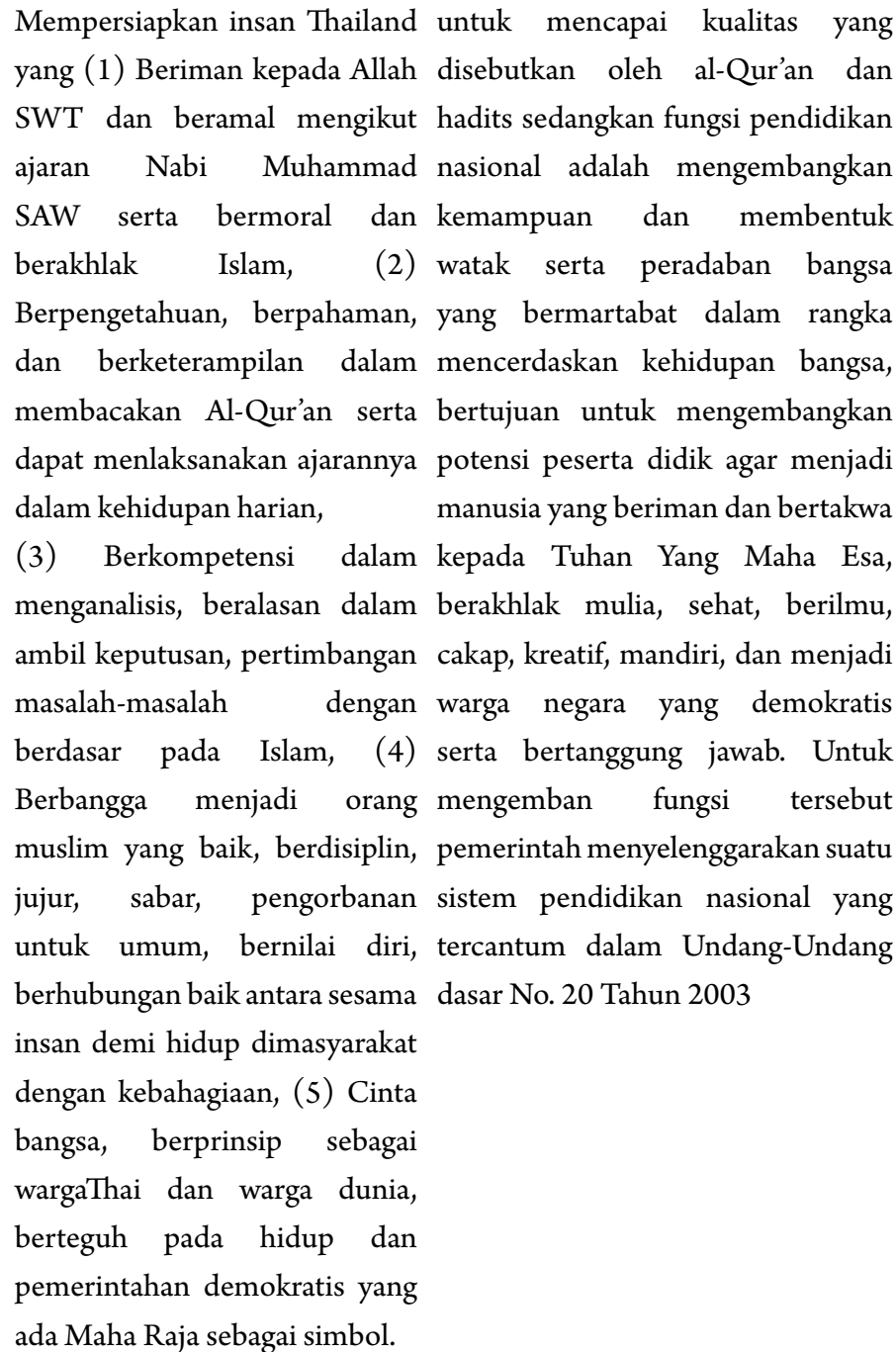 \\
\hline
\end{tabular}

Sumber: data diolah dari berbagai sumber

Pada Tabel 1., penulis dapat ambil pemahaman bahwa Pendidikan dan kurikulum merupakan suatu kebijakan negara yang di pertanggungjawabkan oleh pemerintah dalam mengembangkan rakyat penduduk, terutama di aspek keagamaan termasuk juga agama Islam, Kristian, katolik dan lainnya.

Implementasi kurikulum 2013 pada pendidikan agama Islam secara umumnya dimulai pada tahun pelajaran 2013/2014 di tingkat pendidikan dasar dan menengah setelah di canangkan oleh 
pemerintah. Kurikulum 2008 diterapkan pada tahun akademik 2009/2010 setelah di canangkan oleh pemerintah negara. Hal ini merupakan suatu kebijakan bagi pemerintah terhadap kepentingan pendidikan dalam upaya mengembangkan supaya rakyat penduduk memiliki mutu kehidupan. Sementara di tinjau pada prinsip bahwa kurikulum pendidikan direncanakan atas dasar kebangsaan untuk mengembang peserta didik di aspek sikap, pengetahuan, dan keterampilan sama ada di sekolah atau diluar sekolah.

Dengan demikian yang menarik bahwa tujuan pendidikan secara umum adalah mendidik peserta didik menjadi insan yang bertakwa, beriman, berkreatif, memecahkan masalah serta memiliki potensi kecakapan dalam kehidupan di masyarakat baik secara kepribadian atau kelompok yang diharapkan dan diinginkan bersama dari dua kurikulum pendidikan nasional.

\section{Kompetensi Lulusan PAI}

Pada pembelajaran PAI Indonesia berdasarkan pada Permendikbud 20 tahun 2016 bahwa standar kompetensi lulusan di tekankan dapa tiga aspek yaitu sikap (spiritual dan sosial), pengetahuan, dan keterampilan seimbang dengan pembelajaran PAI di Thailand yang terdapat pada kurikulum nasional.

Berdasarkan data yang terdapat bahwa mata pelajaran Pendidikan Agama Islam pada Sekolah Menengah Atas (SMA) umumnya di Indonesia yang dimaksud adalah mata Pendidikan Agama Islam dan Budi Perkerti yang merupakan mata pelajaran wajib yang meningikan hasil peserta didik yang beriman, bertaqwa, berilmu, bertanggung jawab, sehat, cakap, kreatif, mandiri, dan demokratis. Sementara di Thailand terdapat pada mata pelajaran Pendidikan Agama Islam yang diinginkan hasil perseta didik yang bercinta bangsa, agama, dan raja, kejujuran dan integritas, berdisiplin diri, aviditas untuk belajar, berprinsip-prinsip kepada Filsafat Kemandirian Ekonomi, bergotong royong, bercinta membaca Al-Qur'an, solat, kebersihan, berakhlak Islam, dan bertanggung jawab. Ini merupakan materi mata pelajaran dan tujuan dalam mengembangkan peserta didik untuk menguasainya dengan sepenuh-penuh potensinya.

Pada kedua kurikulum tersebut memiliki persamaan dan perbedaan, adapun tujuan yang sama, yaitu secara umum bagi 
pendidikan agama Islam menurut kurikulum nasional adalah membinakan peserta didik yang beriman, berakhlak Islam, sehat, bertanggung jawab, bercakap, berdisiplin, jujur dan lain-lain dengan membentukan peserta didik menjadi seorang muslim yang baik prilaku dan sempurna pada semua aspek kehidupan.

Ini sesuai dengan pendapat Wichai dan Zakiah Daradjat bahwa tujuan pembelajaran membentukan pengetahuan, keterampilan, sikap yang meingikan peserta yang cakap, kreatif, berkarakteristik yang baik yang dijarkan oleh sekolah atau Lembaga pendidikan (Wongyai, 2011 7; Zakiah Daradjat, 2012 : 123). Adapun perbedaan kedua kurikulum tersebut adalah kondisi dan situasi kehidupan peserta didik dikerenakan kondisi dan situasi Thailand berbeda dengan Indonesia, baik pada bangsa, bahasa, dan budaya. Secara lebih lanjut dijelaskan dalam bentuk Tabel 2 .

Tabel 2. Analisis Perbedaan dan persamaan pada Standar Kompetensi Lulusan

\begin{tabular}{|c|c|c|}
\hline Indikator & Indonesia & Thailand \\
\hline Kompetensi & Peraturan Menteri Pendidikan dan & 1. Kemampuan dalam \\
\hline \multirow{20}{*}{$\begin{array}{l}\text { Lulusan peserta } \\
\text { didik }\end{array}$} & Kebudayaan No. 20 Tahun 2016 & Komunikasi \\
\hline & yang meliputi: & 2. Kemampuan dalam Berpikir \\
\hline & a) Aspek SKL: Sikap Spiritual, & 3. Kemampuan dalam \\
\hline & Sikap Sosial, Pengetahuam, dan & Pemecahan Masalah \\
\hline & Keterampilan. & 4. Kemampuan dalam \\
\hline & b) Tujuan: 1) beriman dan & Menerapkan Kecakapan Hidup \\
\hline & bertakwa kepada Tuhan Yang & 5. Kemampuan dalam Aplikasi \\
\hline & Maha Esa, berakhlak mulia, dan & Teknologi. \\
\hline & berkepribadian luhur; 2) berilmu, & 6. Kemampuan dalam \\
\hline & cakap dalam berpikir, kritis dalam & membaca Al-Qur'an \\
\hline & menanggapi situasi dan kondisi, & \\
\hline & kreatif dalam melaksanakan & \\
\hline & pembelajaran, dan inovatif dalam & \\
\hline & bertindak; 3) sehat secara jasmani & \\
\hline & dan rohani, mandiri, dan percaya & \\
\hline & diri dalam hal postif, dan 4) toleran & \\
\hline & terhadap sesama, mempunyai & \\
\hline & sikap peka sosial, demokratis, & \\
\hline & dan bertanggung jawab dalam & \\
\hline & melakukan segala hal. & \\
\hline
\end{tabular}


Karakteristik Religius, Jujur, Toleransi, Disiplin, Cinta bangsa, agama, dan peserta didik Kerja Keras, dan Kreatif

raja, Kejujuran dan integritas, Berdisiplin diri, Aviditas untuk belajar, Berprinsip-prinsip pada Filsafat Kemandirian Ekonomi, Menghargai nilainilai Thai, Bergotong royong, Cinta membaca Al-Qur'an, Solat, Kebersihan, Berakhlak Islam, dan Bertanggungjawab

Dari Tabel 2., dapat disimpulkan bahwa indikator tujuan, kompetensi lulusan, karakteristik peserta didik dari dua kurikulum Indonesia dan Thailan memiliki tujuan yang sama pada peserta didik, yaitu menyiapkan peserta didik yang memiliki wawasan yang lengkap pada semua aspek kehidupan terutama pada agama Islam yang merupakan agama peserta didik.

\section{Standar Isi Pendidikan Agama Islam}

Standar isi merupakan bahan ajar yang tersusun yang ingin dicapaikan oleh pendidik kepada peserta didik dengan melalui proses pembelajaran yang terintegrasi terdiri dari ranah sikap, pengatahuan, dan keterampilan yang menjadi dasar dalam menentukan standar pembelajaran dan muatannya.

Pada Standar Isi Materi pembelajaran pendidikan agama Islam pada kurikulum 2008 merupakan suatu materi yang tercatum dalam mata kolompak pendidikan sosial, agama dan budaya dan juga terdapat pada mata pelajaran dan kegiatan tambahan dari sekolah yang memiliki kebijakan yang ungul. Diantara muatan Isi yang terdapat dalam standar pembelajaran pendidikan agama Islam meliputi Al-Qur'an, Aqidah, Fiqh, Tarikh, Akhlak, dan Bahasa Arab dan Bahasa Melayu.

Standar isi PAI dalam kurikulum ini dijadikan acuan dalam Standar Pembelajaran (SP) dan Kompetensi Dasar (KD). Pada semua mata pelajaran berdasarkan pada standar pembelajaran dalam menetukan silabus dan RPP dengan maksudnya bahwa kurikulum 2008 ini pemerintah sudah menetu standar pembelajaran (SP), kompetensi dasar $(\mathrm{KD})$, indikator pencapaian dan materi yang akan 
dipelajari oleh peserta didik sebagai menjadi pedoman kecuali mata materi pelajaran tambahan atau mata pendidikan lokal yang belom direncanakan halnya tergantung kepada kebijakan sekolah dan masyarakat setempat.

Sementara standar isi pembelajaran PAI dalam kurilulum 2013 berdasarkan pada Permendikbud No.21 tahun 2016 yang memiliki standar isi turun dari Standar Kompetensi Lulusan (SKL), Kompetensi Inti (KI) dan Kompetensi Dasar (KD). Dari KI-KD diturunkan dalam bentuk mata pelajaran. PAI disini dengan maksud adalah PAI dan BP yang merupakan mata pelajaran wajib bagi peserta didik, kemudian direncana silabus dan RPP pada selanjuknya. Dalam KI merupakan kompetensi yang mencakupi ranah sikap spiritual dan sikap sosial, pengetahuan, dan keterampilan yang meliputi semua mata pelajaran sedangkan KD meliputi hanya mata pelajaran. Secara rinci dapat dianalisis perbedaan dan persamaan pada standar Isi tersebut dapat dijelaskan dalam Tabel 3.

Tabel 3. Analisis perbedaan dan persamaan pada Isi Mata Pelajaran PAI di SMA

\begin{tabular}{|c|c|c|}
\hline Indikator & Kurikulum 2008 & Kurikulum 2013 \\
\hline $\begin{array}{l}\mathrm{R} \text { u a n } \mathrm{g} \\
\text { lingkup }\end{array}$ & $\begin{array}{l}\text { Materi disusun seimbangan dan } \\
\text { mencakup komptensi sikap, } \\
\text { pengetahuan, dan keterampilan }\end{array}$ & $\begin{array}{l}\text { Materi disusun seimbangan } \\
\text { dan mencakup komptensi sikap, } \\
\text { pengetahuan, dan keterampilan }\end{array}$ \\
\hline $\begin{array}{l}\mathrm{Mu} \text { a } \mathrm{t} \text { a } \\
\mathrm{m} \text { a } \mathrm{t} \text { a } \\
\text { pelajaran }\end{array}$ & $\begin{array}{l}\text { PAI meliputi mata pelajaran terpisah } \\
\text { diantaranya: Al-Qur'an, Hadis, Aqidah, } \\
\text { Fiqih, Akhlak, Sejarah, Bahasa Arab, dan } \\
\text { Bahasa Melayu }\end{array}$ & $\begin{array}{l}\text { PAI dan Budi Pekerti secara } \\
\text { terpadu meliputi materi al-Qur'an } \\
\text { dan Hadis, Akidah, Fiqh, Akhlak, } \\
\text { dan Sejarah Peradaban Islam. }\end{array}$ \\
\hline \multirow[t]{5}{*}{$\begin{array}{l}\text { S t a n d a r } \\
\text { pembela } \\
\text { Jaran }\end{array}$} & $\begin{array}{l}\text { Standar Isi acuan dari Standar } \\
\text { Pembelajaran }(\mathrm{SP}) \text { dan Kompetensi } \\
\text { Dasar (KD) }\end{array}$ & $\begin{array}{l}\text { Standar Isiacuan dari Kompetensi } \\
\text { Inti dan Kompetensi Dasar }\end{array}$ \\
\hline & $\begin{array}{l}\text { Mata pelajaran memiliki standar } \\
\text { pembelajaran terpisah dari mata } \\
\text { pelajaran yang berbeda. }\end{array}$ & $\begin{array}{l}\text { Mata pelajaran memiliki } \\
\text { Kompetensi Inti yang sama pada } \\
\text { semua mata pelajaran. }\end{array}$ \\
\hline & $\begin{array}{l}\text { Mata pelajaran lebih khusus dan } \\
\text { mendalam }\end{array}$ & $\begin{array}{l}\text { Mata pelajaran berbentuk } \\
\text { terpadu materi. }\end{array}$ \\
\hline & $\begin{array}{l}\text { Materi pelajaran masih bertindak } \\
\text { kapada pengetahuan dari sikap dan } \\
\text { keterampilam }\end{array}$ & $\begin{array}{l}\text { Materi pelajaran bertindak } \\
\text { kapada sikap, pengetahuan dan } \\
\text { keterampilan bersama-sama. }\end{array}$ \\
\hline & $\begin{array}{l}\text { Semua isi materi seimbangan dengan } \\
\text { pendidikan akklak dan kedamaian }\end{array}$ & $\begin{array}{l}\text { Semua isi materi seimbangan dengan } \\
\text { pendidikan akhlak dan kedamaian }\end{array}$ \\
\hline
\end{tabular}




\begin{tabular}{|c|c|}
\hline Tujuan & 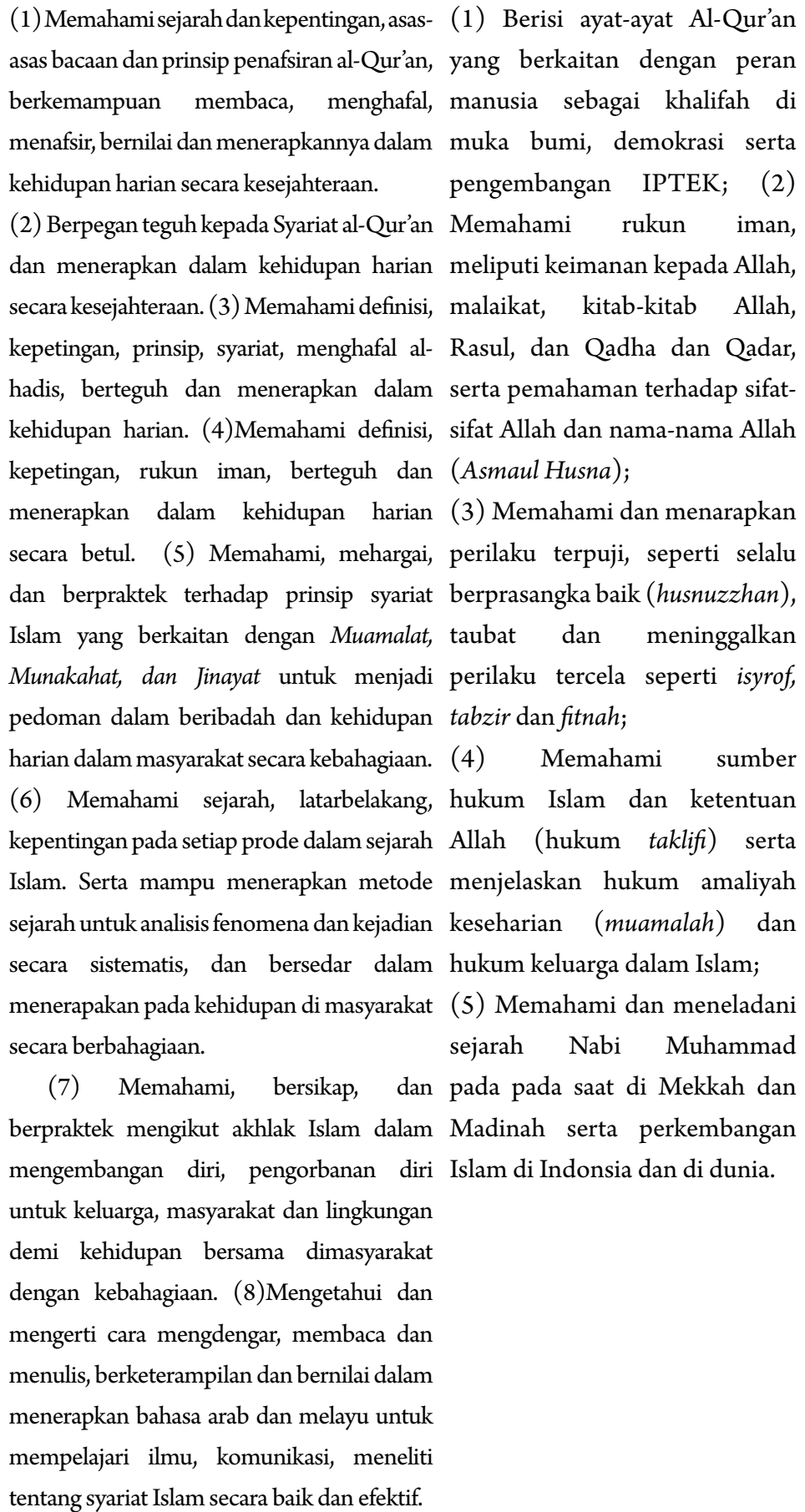 \\
\hline
\end{tabular}




\section{Proses Pembelajaran Pendidikan Agama Islam}

Suatu proses atas diri individu yang dinamis yang berkaitan dengan pemikiran, integritas dan otonminya merupakan salah satu dari tujuan pendidikan. Pada Proses Pembelajaran Pendidikan Agama Islam pada Kurikulum 2013 dan Kurikulum 2008 dapat dijelaskan sebagai berikut:

\section{a. Konsep proses pembelajaran}

Berdasarkan pada UU pendidikan Thailand tahun 1999 pada pasal 23 dan 24 telah menentukan bahwa proses pendidikan menitikberatkan pada pengetahuan dan akhlak. Proses pembelajaran akan dipadu melalui pemahaman, latihan, olah rasa, pikiran, persiapan diri dalam mengadapi situasi yang beragaman, dan mengunakan ilmu pengetahuan untuk mengawasi dan memecahan masalah. Sementara di Indonesia, proses pembelajaran dilakukan dengan mengedepankan prinsip utama kebutuhan peserta didik yang meliputi aspek fisik, emosi, masyarakat dan moral peserta didik, dan seimbang. Hal ini sesuai dengan Peraturan Menteri Pendidikan dan Kebudayaan RI No. 22 tahun 2016 tentang standar proses, yaitu proses pembelajaran mencakup tiga ranah yaitu ranah sikap, pengetahuan, dan keterampilan yang sesuai kebutuhan peserta didik (Permendikbud, 2016).

\section{b. Pendekatan dan metode proses pembelajaran}

Proses pembelajaran PAI di Thailand dilaksanakan dengan pendekatan berpusat kepada peserta didik yang mencakup pengetahuan, sikap dan keterampilan melalui pendekatan proses terpadu, berpikir, mencipta pengetahuan, sosial, pemecahan masalah, belajar dari pengalaman benar, praktek langsung, penelitian, belajar mandiri, dan tindakan akhlak dengan melalui berbagai cara atau metode, seperti ceramah, soal-jawab, perkerjaan rumah, seminar dan kegiatan-kegiatan yang sesuai dengan situasi dan dunia modern.

Sementara proses pembelajaran PAI dan BP mencakup tiga ranah yaitu sikap, pengetahuan, dan keterampilan. Dalam proses pembelajaran akan berbasis pada pendekatan ilmiah yang meliputi: mengamati, menanya, menalar, mencoba, membentuk jejaring. Sedangkan model dalam melaksanakan proses pembelajaran diantara lain model Pembelajran Berbasis Masalah (PBL), Proyek, Penemuan (Discovery Learning), dan Portofolio. Hasil akhirnya adalah 
peningkatan dan keseimbangan antara kemampuan untuk menjadi manusia yang baik (soft skills) dan manusia yang memiliki kecakapan dan pengetahuan untuk hidup secara layak (hard skills) dari peserta didik yang meliputi aspek kompetensi sikap, keterampilan, dan pengetahuan. Ini seimbangan dengan pendapat Mulyana bahwa pelaksanaan proses pembelajaran di sekolah mencakup tiga hal yaitu pretes, pembentukan kompetensi, dan post tes (Mulyasa, 2006 : 256). Selain demikian, secara lebih tergambar dijelaskan dengan melalui Tabel 4.

Tabel 4. Analisis perbedaan dan persamaan pada Proses Pembelajaran PAI bagi SMA

\begin{tabular}{|c|c|c|}
\hline & Kurikulum 2008 & Kurikulum 2013 \\
\hline $\begin{array}{l}\text { Pendekatan } \\
\text { dan metode }\end{array}$ & $\begin{array}{l}\text { Proses pembelajaran bersikap } \\
\text { dengan pendekatan berpusat kapada } \\
\text { siswa dengan melalui: pendenkatan } \\
\text { terpadu, berpikir, mencipta } \\
\text { pengetahuan, sosial, pemecahan } \\
\text { masalah, belajar dari pengalaman } \\
\text { benar, pratek langsung, penelitian, } \\
\text { belajar mandiri, pengembang } \\
\text { akhlak. }\end{array}$ & $\begin{array}{l}\text { Proses pembelajaran dilakukan } \\
\text { dengan menggunakan beberapa } \\
\text { pendekatan seperti, pendekatan } \\
\text { saintifik (mengamati, menanya, } \\
\text { menalar, mencoba, dan } \\
\text { mengkomunikasikan), Model } \\
\text { Pembelajran Berbasis Masalah } \\
\text { (PBL), Proyek, Penemuan dan } \\
\text { Portofolio }\end{array}$ \\
\hline belajar & $\begin{array}{l}\text { Waktu aktif belajar, sekitar } 18-20 \\
\text { minggu persemester, Peserta didik } \\
\text { harus beraktif belajar tidak kurang } \\
\text { diri } 60 \% \text { dari waktu aktif, Waktu } \\
\text { belajar } 1 \text { jam bersama dengan } 45 \\
\text { minit, SKS terpisah mengikut mata } \\
\text { pelajaran }\end{array}$ & $\begin{array}{l}\text { Waktu aktif belajar tidak kurang } \\
\text { dari } 18 \text { minggu persemester, } \\
\text { Peserta didik harus beraktif } \\
\text { belajar tidak kurang diri } 60 \% \\
\text { dari waktu aktif, Waktu belajar } \\
1 \text { jam bersama dengan } 45 \text { minit, } \\
\text { SKS tersendirian mengikut mata } \\
\text { pelajaran }\end{array}$ \\
\hline $\begin{array}{l}\text { Silabus } \\
\text { dan RPP }\end{array}$ & $\begin{array}{l}\text { Silabus sudah disediakan oleh } \\
\text { pemerintah pusat kecuali ada } \\
\text { mata pelajaran tambahan bagi } \\
\text { guru dan sekolah bertanggung } \\
\text { jawab dalam merencanakannya, } \\
\text { Sementara RPP adalah tanggung } \\
\text { jawab setiap guru berbentuk dalam } \\
\text { merencanakannya }\end{array}$ & $\begin{array}{l}\text { Silabus sudah disediakan } \\
\text { oleh pemerintah pusat, hanya } \\
\text { bagi guru merencakan dalam } \\
\text { berbentuk RPP. RPP setiap } \\
\text { gurudiwajibkan direncanakan } \\
\text { berbentuk pribadian atau } \\
\text { berkolompak }\end{array}$ \\
\hline
\end{tabular}




\section{Penilaian Pendidikan Agama Islam (PAI)}

Standar penilaian merupakan laporan nilai hasil belajar peserta didik dalam mengambil keputusan terhadap satu satuan pendidikan. Dengan mengadakan penilaian, hasil positif atau negatif yang terdapat dari proses pembelajaran tersebut merupakan dampak dari suatu sistem program pendidikan. Beberapa pokot yang berkaitan tentang penilaian kurikulum PAI antara di Indonesia dan di Thailand yaitu: Tahap penilaian,

Tahap penilaian adalah tingkatan penilaian dalam suatu pendidikan. Pada pendidikan di Thailand bahwa penilaian Pembelajaran PAI meliputi 4 tingkat penilaian yaitu tingkat kelas, tingkat sekolah, tingkat layanan pendidikan daerah, dan tingkat nasional (Kementerian pendidikan, 2010:36-37). Pada penilaian semua tingkat sudah diterapkan kecuali penilaian tingkat layanan pendidikan daerah. Penilaian tingkat kelas, menggunakan beragam penilaian diantaranya Penialaian komunikatif keperibadian, Penilaian Kinerja (Performance Assessment), Penilaian Authentik, dan Penilaian Portfolio. Sedangkan penilaian tingkat sekolah, pada umumnya mengunakan ujian tes, sama ada dalam bentuk tes lisan dan tes tulis di akhir setiap semester pembelajaran, dan Penilaian tingkat Nasional dengan melalui tes tulis hanya untuk bagi peserta didik pada kelas 12 atau mathyom 6 yang dinamakan ujian I-NET, adapun pada kelas 10 dan 11 hanya cukup pada sekadar penilaian tingkat kelas dan tingkat sekolah. Sementara di Indonesia menurut Permendikbud 23 tahun 2016 bahwa penilaian hasil belajar pada satuan pendidikan dasar dan menengah dilakukan oleh pendidik, satuan sekolah, dan pemerintah. Penilaian hasil belajar PAI dilakukan dalam bentuk otentik, penilaian diri, penilaian projek, penilaian harian, penilaian tengah semester (PTS), penilaian akhir semester (PAS), ujian sekolah, dan ujian nasional (UN).

Dari mengamati disini bahwa posisi penilaian hasil belajar antara dua kurikulum memiliki persamaan yaitu ada pada tingkat kelas, sekolah, dan nasional. Adapun yang memiliki perbedaan pada PAI, adalah pada tingkat nasional di Indonesia belom diterapkan, oleh kerena belom memiliki kesiapan secara baik sebagai mana di ungkapkan oleh Feisal Ghozali (2017: wawacara) dari pusat 
kurikulum dan perbukuan RI. Yang berikut dapat dijelaskan dalam Tabel 5.

\section{Tabel 5. Analisis Perbedaan dan Persamaan pada Penilaian Pembelajaran PAI bagi SMA}

\begin{tabular}{|c|c|c|}
\hline & Kurikulum 2008 & \\
\hline $\begin{array}{l}\text { Pendekatan } \\
\text { dan Metode }\end{array}$ & $\begin{array}{l}\text { Penilaian kompetensi } \\
\text { keperibadian, Penilaian Kinerja } \\
\text { (Performance Assessment), } \\
\text { Penilaian otentik, Penilaian } \\
\text { Portofolio }\end{array}$ & $\begin{array}{l}\text { Penilaian pembelajaran } \\
\text { pendekatan otentik, melalui } \\
\text { metode penilaian pretasi, } \\
\text { penilaian kinerja, penilaian } \\
\text { proyek, dan penilaian portofolio. }\end{array}$ \\
\hline $\begin{array}{l}\mathrm{R} \text { u a } \mathrm{n} \text { g } \\
\text { lingkup }\end{array}$ & $\begin{array}{l}\text { Attitude, pengetahuan, dan } \\
\text { keterampilan }\end{array}$ & $\begin{array}{l}\text { Aspek sikap spiritual dan sosial, } \\
\text { pengetahuan, serta keterampilan }\end{array}$ \\
\hline $\begin{array}{l}\text { T a h a p a } \mathrm{n} \\
\text { penilaian }\end{array}$ & $\begin{array}{l}\text { Terbagi kepada } 4 \text { tahap yatui: } \\
\text { tingkat kelas, tingkat sekolah, } \\
\text { tingkat daerah (tapi belum } \\
\text { diterap), dan tingkat nasional }\end{array}$ & $\begin{array}{l}\text { Terbagi kepada } 3 \text { tahap yaitu: } \\
\text { Kelas, Sekolah, dan Nasional } \\
\text { (tapi tahap Nasional belom } \\
\text { diterapkan) }\end{array}$ \\
\hline nggung & $\begin{array}{l}\text { Pendidik, Sekolah, dan Badan } \\
\text { Standar Jaminan Mutu Pendidikan } \\
\text { Nasional }\end{array}$ & $\begin{array}{l}\text { Pendidik, Satuan Sekolah, Badan } \\
\text { Standar Nasional Pendidikan } \\
(\mathrm{BSNP})\end{array}$ \\
\hline $\begin{array}{l}\text { Kriteria dan } \\
\text { skor nilai }\end{array}$ & $\begin{array}{l}\text { Penilaian Pengetahuan melalui } \\
\text { Predikat } 5 \text { tahap yaitu: Baik } \\
\text { Sekali (A), Baik (B), Cukup (C), } \\
\text { Kurang (D), dan Tidak Lulus } \\
\text { (F), Sementara Nilai Karekter } \\
\text { memiliki } 4 \text { tahap yaitu: Baik Sekali } \\
\text { (A), Baik (B), Lulus (C-D), dan } \\
\text { Tidak Lulus (F), dan nilai kegiatan } \\
\text { memiliki predikat } 2 \text { tahap yaitu: } \\
\text { Lulus (A-C) dan Tidak Lulus (F). }\end{array}$ & $\begin{array}{l}\text { Penilaian pengetahuan, sikap dan } \\
\text { keterampilan dengan predikat } \\
\text { yang sama melalui } 4 \text { tahap } \\
\text { predikat yaitu: Baik Sekali (A), } \\
\text { Baik (B), Cukup (C), Kurang } \\
\text { (D). }\end{array}$ \\
\hline
\end{tabular}

Didasarkan Tabel 5. menunjukan bahwa guru, sekolah, dan pemerintah berperan sebagai pengukur dan menilaikan hasil belajar kepada peserta didik yang terdapat hasil prilaku peserta didik yang nyata. Dengan melului berbagai instrumen yang telah disiapkan yang memberi dampak positif dan nagatif terhadap pendidikan, yang dimaksud dengan positif yaitu hasil belajar dapat dilanjutkan dan mengembang lebih tinggi secara lebih optimal, sedangkan yang dimaksud dengan nagatif yaitu hasil belajar dapat dinilai kembali serta diperbaikan dengan baik yang terdapat dari proses pembelajaran 
atau bentuk bertindak dalam mengukur dan menilai peserta didik. Perbedaan dan persamaan secara umum pada kurikulum PAI di SMA dapat dilihat dalam Tabel 7.

Tabel 7. Analisis perbedaan dan persamaan secara umum esensi Kurikulum di SMA

\begin{tabular}{|c|c|}
\hline Kurikulum 2008 & Kurikulum 2013 \\
\hline $\begin{array}{l}\text { Satu Mata pelajaran hanya mendukung } \\
\text { kompetensi tertentu. }\end{array}$ & $\begin{array}{l}\text { Setiap mata pelajaran bertanggung } \\
\text { jawab dalam mendukung pemenuhan } \\
\text { kompetensi sikap, keterampilan, dan } \\
\text { pengetahuan dengan penekanan yang } \\
\text { berbeda }\end{array}$ \\
\hline $\begin{array}{l}\text { Setiap Mata pelajaran memiliki } \\
\text { kompetensi dasar berbeda satu sama lain }\end{array}$ & $\begin{array}{l}\text { Mata pelajaran diracang terkait } \\
\text { satu dengan yang lain dan memiliki } \\
\text { kompetensi dasar yang diikat oleh } \\
\text { kompetensi inti setiap kelas }\end{array}$ \\
\hline $\begin{array}{l}\text { Bahasa Thailand dan Melayu sebagai } \\
\text { pengatar dan pengetahuan }\end{array}$ & $\begin{array}{l}\text { Bahasa Indonesia menjadi alat komunikasi } \\
\text { dan pengetahuan }\end{array}$ \\
\hline $\begin{array}{l}\text { Setiap mata pelajaran diberikan dengan } \\
\text { pendekatan yang berbeda satu sama lain }\end{array}$ & $\begin{array}{l}\text { Semua mata pelajaran diajarkan melalui } \\
\text { berbagai pendekatan yang mengarahkan } \\
\text { pembelajaran siswa aktif, meliputi } \\
\text { scinetific approach, problem based } \\
\text { learning, project based learning, inkuiri } \\
\text { learning. }\end{array}$ \\
\hline $\begin{array}{l}\text { Mata pelajaran PAI di SMA merupakan } \\
\text { wajib yang diajarkan kepada siswa oleh } \\
\text { sekolah yang memiliki siswa muslim dan } \\
\text { program PAI }\end{array}$ & $\begin{array}{l}\text { Mata pelajaran PAI di SMA merupakan } \\
\text { mata pelajaran wajib yang diajar kepada } \\
\text { siswa muslim }\end{array}$ \\
\hline $\begin{array}{l}\text { Penyusunan silabus oleh pemerintah, } \\
\text { sedangkan guru pengembangan dari yang } \\
\text { sudah disiapkan melului RPP }\end{array}$ & $\begin{array}{l}\text { Penyusunan Silabus oleh Pemerintah, } \\
\text { guru pengembangan dari yang sudah } \\
\text { disiapkan melului RPP }\end{array}$ \\
\hline
\end{tabular}

Dan juga di sini terdapat beberapa butir kelebihan dan kelemahan yang menjadikan dampak terhadap kurikulum nasional seperti yang diajukan dalam tabel sebagai berikut: 
Tabel 8. Kelebihan dan Kekurangan Kurikulum 2008 dan Kurikulum 2013

\begin{tabular}{|c|c|c|}
\hline No & Kurikulum 2008 & alum 2013 \\
\hline \multicolumn{3}{|c|}{ KELEBIHAN } \\
\hline 1 & $\begin{array}{l}\text { Sekolah memiliki kurikulum yang } \\
\text { sama menunjukan kesatuan dalam } \\
\text { proses pembelajaran dan lebih mudah } \\
\text { dilaksanakannya }\end{array}$ & $\begin{array}{l}\text { Menekankan pada akhlak al-karimah } \\
\text { dan karakter }\end{array}$ \\
\hline 2 & $\begin{array}{l}\text { Membantu siswa untuk memiliki waktu } \\
\text { yang cukup serta seimbang dengan } \\
\text { kebiasaan dan titikberat sekolah. }\end{array}$ & $\begin{array}{l}\text { Soft skills dan hard skills (sikap, } \\
\text { keterampilan dan kompetensi) }\end{array}$ \\
\hline 3 & $\begin{array}{l}\text { Membantu dalam mengukur tentang } \\
\text { kualitas siswa pada semua lapisan secara } \\
\text { lebih jalas dan bisa diperbaikan siswa } \\
\text { betul dengan indikatornya. }\end{array}$ & $\begin{array}{l}\text { Aktif, kreatif dan inovatif merupakan } \\
\text { tuntutan bagi siswa. }\end{array}$ \\
\hline 4 & $\begin{array}{l}\text { Membantu lembaga pendidikan dalam } \\
\text { mengembangkan kurikulum secara lebih } \\
\text { utuh yang berdasar kepada kurikulum inti } \\
\text { secara optimal. }\end{array}$ & $\begin{array}{l}\text { Standar penilaian berbasis pada } \\
\text { kompetensi sikap, ketrampilan dan } \\
\text { pengetahuan secara proporsional. }\end{array}$ \\
\hline \multicolumn{3}{|c|}{ KELEMAHAN } \\
\hline 1 & $\begin{array}{l}\text { Proses pembelajaran bertindak pada } \\
\text { aspek pengetahuan lebih dari aspek } \\
\text { keterampilan dan sikap }\end{array}$ & $\begin{array}{l}\text { Guru kurang diberikan kesempatan } \\
\text { dalam mengembangkan } \\
\text { dalam menyusun silabus mata } \\
\text { pembelajaran }\end{array}$ \\
\hline 2 & $\begin{array}{l}\text { Guru tidak berkembang dalam menyusun } \\
\text { silabus mata pelajaran }\end{array}$ & $\begin{array}{l}\text { Sekolah tidak mandiri dalam } \\
\text { menyikapi kurikulum }\end{array}$ \\
\hline 3 & $\begin{array}{l}\text { Sekolah tidak mandiri dalam menyikapi } \\
\text { kurikulum }\end{array}$ & $\begin{array}{l}\text { Tugas menganalisis SKL, KI, KD } \\
\text { sudah ada, guru hanya menerapkan } \\
\text { yang sudah ada. }\end{array}$ \\
\hline 4 & $\begin{array}{l}\text { Guru Pendidikan Agama Islam dipisahkan } \\
\text { mengikut minat dan kapadaiannya }\end{array}$ & $\begin{array}{l}\text { Pendidikan Agama Islam memiliki } \\
\text { materi pelajaran secara lebih umum }\end{array}$ \\
\hline
\end{tabular}

\section{Simpulan}

Simpulan berisi jawaban dari rumusan masalah penelitian. Simpulan merupakan intisari dari pembahasan dan hendaknya merupakan jawaban atas pertanyaan penelitian dengan bentuk diskriptif. Simpulan ditulis sendiri-sendiri dalam sub judul. Simpulan memuat jawaban atas pertanyaan penelitian. Ditulis dalam bentuk 
narasi, bukan dalam bentuk numerikal/numbering. Saran diberikan atas dasar hasil penelitian.

Kebijakan kurikulum merupakan seperangkat aturan sebagai bentuk keberpihakan dari pemerintah dalam upaya membangun satu sistem pendidikan sesuai dengan tujuan dan cita-cita yang diinginkan bersama. Pada kebijakan penerapan kurikulum 2013 di Indonesia adalah berdasarkan kepada Undang-Undang Sistem Pendidikan National seperti No.20 Tahun 2003 sementara kurikulum 2008 di Thailand berdasar kepada UU tahun 1999 pasal 6 dan surat keputusan kementerian no. 293/2551, dan surat keputusan kementerian pendidikan dasar tanggal 19/4/2553. Dalam kebijakan penerapan dua kurikulum tersebut, pemerintah dapat merencanakan dan mengeluarkan beberapa butir kebijakan seperti: menyiapkan perencanaan, strategi penerapan, menyiapkan kursus kurikulum, menyediakan guru mengajar, menjadwalkan pengajar, membuat sarana pembelajaran, mengumumkan, mengalokasikan waktu dan kegiatan pengembangkan kurikulum, serta mengadakan sistem evaluasi. Dalam sistem kurikulum yang berkaitan dengan kependidikan secara langsung yang meliputi standar kelulusan, standar isi, standar proses pembelajaran, dan standar penilaian.

Pada standar kelulusan kurikulum 2013 berdasarkan pada Permendikbud No. 20 tahun 2016 tentang Standar Kompetensi Lulusan (SKL) yang meliputi aspek sikap spiritual, sikap sosial, pengetahuan, dan keterampilan. Sementara Kurikulum 2008 yang mencakup pengetahuan, sikap, dan keterampilan terhadap Kemampuan dalam komunikasi, berpikir, pemecahan masalah, kecakapan hidup, aplikasi teknologi, dan membaca Al-Qur'an. Pada standar isi, Kurikulum 2013 berdasarkan pada Permendikbud No.21 tahun 2016 tentang standar isi. Standar isi beracuan dari SKL yang diturunkan berbentuk Kompetensi Inti (KI) dan Kompetensi Dasar (KD) yang terdapat pada mata pembelajaran Pendidikan Agama Islam dan Budi Pekerti yang meliputi didalamnya pembelajaran AlQur'an dan Hadis, Aqidah, Fiqih, Akhlak, dan Sejarah Peradaban Islam dengan materi secara lebih terpadu semenrata Kurikulum 2008 bahwa standar isi diadakan dalam berbentuk Standar Pembelajaran (SP) yang meliputi di dalamnya mata pelajaran Al-Qur'an, Hadis, 
Aqidah, Fiqh, Akhlak, Sejarah, Bahasa Arab, dan Bahasa Melayu dengan secara tepisah mata pelajaran.

Pada standar proses. Pada Kurikulum 2013 berdasarkan pada Permendikbud No. 22 Tahun 2016 yang dilaksanakan proses pembelajaran dengan melului pendekatan ilmiah (scientific approach) yang terdiri dari kegiatan mengamati, menganalisa, menalar, mencoba, dan membentuk jejaring atau relasi. Kurikulum 2008 dilaksanakan dengan pendekatan yang berpusat pada peserta didik, hal tersebut terdiri dari pendekatan terpadu, berpikir, mencipta pengetahuan, sosial, pemecahan masalah, belajar dari pengalaman benar, praktek langsung, penelitian, belajar mandiri, tindakan akhlak.

Pada standar penilaian, Penilaian hasil belajar pada Kurikulum 2013 berdasarkan pada Permendikbud No. 23 Tahun 2016 dilakukan dengan penilaian otentik (authentic assessment) yang mencakup pada ranah sikap, pengetahuan dan keterampilan. Penilaian otentik yang terdapat dari penilaian Tes (tulis dan lisan), Kinerja, Proyek dan Portofolio dengan melalui penilaian pada tingkat kelas dan tingkat satuan pendidikan, dan tingkat nasional tetapi bagi PAI belum dijalankan. Sementara dengan Kurikulum 2008 bahwa penilaian hasil belajar dilakukan dengan melalui Penilaian komunikasi kepribadian, Penilaian Kinerja (Performance Assessment), Penilaian Autentik, Penilaian Portofolio dengan meliputi penilaian pada tingkat kelas, tingkat sekolah, tingkat nasional adapun tingkat pelayanan pendidikan belum diterapkan.

Namun, pada dua kurikulum ini memiliki keunggulan seperti siswa lebih dituntut untuk aktif, keratif dan inovatif dalam setiap kegiatan pembelajaran dan proses pembelajaran proses pembelajaran dan proses penilaian hasil belajar pada semua aspek yang terdapat dari dua kurikulum adalah bertujuan bahwa peserta didik mengembangkan diri dan bisa hidup di masyarakat dengan aman, damai dan harmonis dan adapun kelemahannya seperti kurikulum sudah siapkan oleh pemerintah membuat sekolah tidak mandiri dalam menyikapi kurikulum dan membuat guru tidak berkembang dalam menyusun silabus dan RPP secara mandiri. 


\section{DAFTAR PUSTAKA}

Ainiyah, N. (2013). Pembentukan Karakter Melalui Pendidikan Agama Islam. Al-Ulum: Jurnal Studi Islam, 13(1), 25-38.

Arifin, M. (2014). Filsafah pendidikan Islam. Jakarta: Bumi Aksara.

Fauzan. (2017). Kurikulum dan Pembelajaran. Tangerang Selatan: Gaung Persada Press.

Ghozaly, F. (2017). Wawancara Pusat Kurikulum dan Perbukuan Kementerian Pendidikan dan Kebudayaan, Jakarta RI. Jakarta.

Gunawan, H. (2014). Pendidikan Islam Kajian Teoritis dan Pemikiran Tokoh. Bandung: Remaja Rosdakarya.

Hamalik, O. (2013). Dasar-dasar Pengembangan Kurikulum (Cetakan 5). Bandung: Remaja Rosdakarya.

Idi, A. (2014). Pengembangan kurikulum Teori \& Praktik. Jakarta: Raja Grafindo Persada.

Ismail, S. M. (2016). Mafahim Miftahiyah Fil Manahij wa Turuqil Tadris. Retrieved March 30, 2016, from www. reseaechgate. net

Kasir, I. (1979). Tafsir Al-Quran Al-Karim. Birut: Dar-Al-Indelus.

Kebudayaan, P. M. P. dan. Peraturan Menteri Pendidikan dan Kebudayaan Nomor 22 Tahun 2016 tentang Standar Proses. , (2016).

Majid, A. (2014). Implementasi Kurikulum 2013 kajian Teoretis dan Praktis. Bandung: Interes Media.

Marliana. (2013). Anatomi Kurikulum Pendidikan Agama Islam di Sekolah. Dinamika Ilmu, 13(2), 137-160.

Mohamad Ansyar. (2015). Kurikulum Hakikat, Fondasi, Desain dan Pengembangan (Cetakan 1). Jakarta: PT. Kencana.

Mulyasa, E. (2006). Kurikulum Tingkat Satuan Pendidikan: Sebuah Panduan Praktis. Bandung: Remaja Rosdakarya.

Nasional, K. anggota pendidikan. (2002). Pan Kan Seksa Heang Chat 2002-2016. Bangkok: Kantor anggota pendidikan nasional.

Nasution, S. (2003). Asas-Asas Kurikulum. Jakarta: Bumi Aksara. 
Nata, A. (2012). Manajemen Pendidikan Mengatasi Kelemahan Pendidikan Islam di Indonesia. Jakarta: Kencana Predana Media.

Pendidikan, K. (1999). Undang-undang Pendidikan National 1999. Bangkok: Khurusapa Ladprau.

Pendidikan, K. (2010). Kurikulum Pendidikan Islam 2008. Bangkok: Chumnumsahakon Kasead Thailand.

Saepudin, J. (2013). Pengembangan Kurikulum PAI di sekolah Unggulan: Studi pada SMP terianN2 Kota Bandar Lampung. Jurnal Penamas, 26(2), 29-47.

Sugiyono. (2013). Metode Penelitian Kuantitatif, Kualitatif dan RઐD. Bandung: Alfabeta.

Sukmadinata, N. S. (2016). Pengembangan Kerikulum Teori dan Pratik. Bandung: Remaja Rosdakarya.

Syukur, F. (2013). Manajemen pendidikan barbasis pada Madrasah (Cetakan 2). Semarang: Pustaka Rizki.

Tafsir, A. (2014). Ilmu Pendidikan dalam Perspektif Islam. Bandung: Remaja Rosdakarya.

UU RI No.20 Tahun 2003 tentang Sistem Pendidikan Nasional. (n.d.). Departement Pendidikan dan Kebudayaan.

Wongyai, W. (2011). Kan pattana laksut radap udom seksa. Retrieved from http://www.curriculumandlearning.com

Zakiah Daradjat, D. (2012). Ilmu Pendidikan Islam. Jakarta: Bumi Aksara. 